\title{
THE EFFECT OF LEVERAGE, SALES GROWTH AND LIQUIDITY TO THE FIRM VALUE OF REAL ESTATE AND PROPERTY SECTOR IN INDONESIA STOCK EXCHANGE
}

\author{
Fery Citra Febriyanto \\ Pamulang University \\ ferycitra.febriyanto@gmail.com
}

\begin{abstract}
The value of the firm is essential for the company so as to Determine the factors thataAffect the company into something that needs to be done. This study aims to examine some of the factors that affect the value of the firm are: leverage, sales growth, liquidity, dividend policy, and firm size on firm value of real estate and property in the Indonesia Stock Exchange. This study uses the entire real estate and property company in Indonesia Stock Exchange period of 2011 to 2015, so there are 41 companies as research samples. This study using Tobin's $Q$ to measure the value of the firm. The results Showed that positive leverage effect on the value of the firm due to debt levels are still optimized so that provide positive implications on additional debt. The study of the liquidity variables shows that liquidity negatively affect the value of the firm due to the value of liquidity are at a maximum. Then the control variable, dividend policy affect the value of the firm and firm size has no effect on the value of firms in the real estate sector and property in the Indonesia Stock Exchange.
\end{abstract}

Keywords : Tobin's Q, Debt to Equity Ratio, Sales Growth, Current Ratio

\section{INTRODUCTION}

The study was conducted at the Real Estate and Property sectors listed on the Indonesian Stock Exchange. The study was based on economic growth affects the fluctuating property growth conditions, but tends to decline beginning in 2015 and four years earlier. It was described in 2012 as the reduction in the sales of real estate and property sector one of which is reflected by PT Bakrieland Development Tbk, which divested its subsidiary, PT Bakrie Toll Road (BTR) and remove the Lido Lake Resort project. This is done in an effort to reduce its debt loan. (Issa Almawadi, 2012, from http://m.kontan.co.id/news/elty- pastikan-jual-btr-dan-lido-resort/, May 7, 2015). In addition to the Bakrie Group-owned property company, PT Agung Podomoro Land Tbk (APLN) recorded a marketing sales decline of about 94.61 percent to Rp 939.7 billion in the first quarter of 2015. Growth in marketing sales decreased significantly due to the market still tends to be quiet in the first quarter of 2015. (Andri Wiranuari, 2015, http://properti.liputan6.com/read/221232 4/pajak-properti-belum-jelas-penjualanagung-Podomoro-merosot/, May 7th, 2015). Chairman of the Central Board Indonesian Real Estate Eddy Hussi noted sales of real estate and property sector has decreased by 25 percent in early 2015 . 
The condition is contradictory to the conditions of national economic growth, which reached $4.67 \%$ close to the target of $5 \%$, in addition to the economic policy package released by the government should be able to give a positive value in the market thereby increasing the value of firm real estate and property sector.

With the background of the problems above, this study attempted to examine how the influence of the use of debt which is reflected in the leverage ratio, sales growth, and liquidity of the firm's value is measured by the ratio of Tobin's Q with the dividend policy and firm size as control variables in the firm sector of real estate and property in The Indonesia Stock Exchange, with the observation period 2011 to 2015 .

\section{LITERATURE REVIEW}

\subsection{Firm Value}

The firm's value can be defined as the fair value of companies that describe investor perception of the relevant issuer . Value of the firm is understood as the market value of the debts on the outstanding securities in the capital markets or the price willing to be paid by the prospective buyer. This study uses one of the factors used in the approach to examine the value of the firm to approach the stock price using the ratio of Tobin's Q. The reason for choosing Tobin'q ratio in this study to measure the value of the firm is due to calculation of Tobin's $Q$ ratio is more rational given the elements of liability also inserted as the basis for calculation.

\subsection{Leverage}

Leverage relates to how the use of debt in financing efforts related to company operations. The use of debt as an additional investment to fund the company's assets is expected to increase the profits to be gained rather than by using its own limited amount of capital.

Basically leverage has a positive influence on the value of the firm due to the addition of funding sourced from the debt leverage ratio, it will provide benefits for the company. In the tradeoff theory said that the addition of debt in the capital structure positions under optimal point will increase the value of the firm.

\subsection{Sales Growth}

The company growth is an indicator of the results of the previous success of the investment period. The company can be said to experience growth if there is a consistent increase of activity during its operation. The company's sales growth is understood as an increase in sales from year to year, or as an indicator of increased market share of the company. For companies that have high sales growth, the company also has a good growth. The positive implications also be interpreted positively by investors as the company has good prospects for the future, thereby increasing the value of the firm.

\subsection{Liquidity}

The liquidity ratio is the ratio of that assess the company's ability to meet its obligations in the short term, where the ability to pay all short-term financial obligations at maturity using the current assets of the company. The liquidity ratio reflects the condition of cash on current assets, if the higher ratio of liquidity then describe the more funds available for the company to pay its obligations. The liquidity ratio can be described in the current ratio. Current ratio is a comparison of the current assets by current liabilities.

So it can be said that the company is able to meet its obligations at maturity means the company is liquid, liquid companies means the company has 
payment instruments or assets are greater than current liabilities or shortterm debt. If the company is said to be illiquid investors will have a positive perception because the company is considered able to meet its financial obligations on time. The positive investor perception of the company that liquid then the value will increase because of the above.

\section{RESEARCH METHOD}

\subsection{Research Design}

In this study used population of the entire real estate and property company listed in Indonesia Stock Exchange period 2011 to 2015. Based on data from BEI (www.idx.co.id) real estate and property company listed on the Stock Exchange is 41 companies.

Linear regression analysis is used in this research to know or get a picture of the influence of independent variables on the dependent variable. The regression model used in this study are multiple linear regression model. This analysis is done with the help of computer program Statistical Package for Social Science (SPSS).

Regression model:

$$
\begin{array}{r}
\text { TQI }=\alpha+{ }_{\beta} 1 \text { DERi }+{ }_{\beta} 2 \text { GROWTHi }+ \\
{ }_{\beta} 3 \text { CRi }+{ }_{\beta} 4 \text { DPRi }+{ }_{\beta} 5 \text { SIZEi }+e
\end{array}
$$

Explanation :

$$
\begin{array}{ll}
\text { TQI } & : \text { Tobin's Q Company i } \\
\alpha & : \text { constants }
\end{array}
$$

$\begin{array}{ll}\beta & : \text { Regression Coefficients } \\ \text { e } & \text { : Error } \\ \text { Deri } & : \text { Debt to Equity Ratio } \\ & \text { Company i } \\ \text { GROWTHi: } & \text { Sales Growth Company i } \\ \text { CRI } & \text { : Company's Current Ratio i } \\ \text { DPRI } & \text { : Dividend Payout Ratio } \\ & \text { Company i } \\ \text { SIZEi } & \text { : Firm Size Company i }\end{array}$

The hypothesis in this study is based on previous discussion are :

$\mathrm{H}_{1}$ : Leverage positively affects on the value of the firm

$\mathrm{H}_{2}$ : Sales Growth positively affects on the value of the firm

$\mathrm{H}_{3}$ : Liquidity positively affects on the value of the firm

\section{RESULTS AND DISCUSSION}

\subsection{Desctiptive Statistics}

Descriptive statistics in this study are presented to provide information about the characteristics of the study variables. Based on the overview of descriptive statistics to know the number of the population studied as many as 41 samples of the company, in the descriptive statistics can be seen the value of the mean, and the deviation rate spread (standard deviation) of the variables studied. The variables used were Tobbin's Q, Debt to Equity Ratio

\begin{tabular}{|c|c|c|c|c|c|}
\hline \multirow[b]{2}{*}{ Model } & \multicolumn{2}{|c|}{$\begin{array}{l}\text { Unstandardized } \\
\text { Coefficients }\end{array}$} & \multirow{2}{*}{$\begin{array}{c}\text { Standardized } \\
\text { Coefficients }\end{array}$} & \multirow[b]{2}{*}{$\mathrm{T}$} & \multirow[b]{2}{*}{ Sig. } \\
\hline & B & Std. Error & & & \\
\hline \begin{tabular}{|l|l|}
1 & (Constant)
\end{tabular} & 1.044 & .896 & & 1.165 & .246 \\
\hline DER & .021 & .009 & .193 & 2.400 & .017 \\
\hline GROWTH & .090 & .035 & .175 & 2.564 & .011 \\
\hline
\end{tabular}
(DER), Sales Growth, Current Ratio, Dividend Payout Ratio (DPR) and Firm Size 


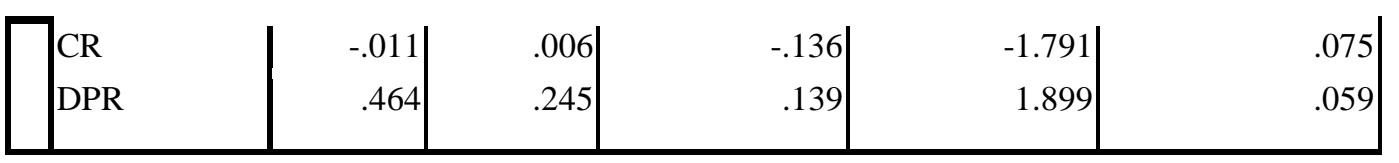

In the TQ variable average value obtained observation period amounted to 0.9274 with a standard deviation of 1.24216 , it can be seen that the average value of real estate and property company approaches the one year observation signifies companies are in average condition. The minimum value is obtained by 0.13 or less than 1 , which means that the market value is less than the value of the assets of companies listed or can be said that the stock in undervalued condition. While at the maximum value obtained by 16.30 or 16.30 times the market value of the book value, the value is greater than 1 , which means also that the market value is greater than the value of the assets of companies listed or overvalued condition.

In the DER variable the average value of observation period is 0.9266 with a standard deviation of 0.80343 , it can be seen that the average DER of real estate and property companies is still low. Minimum value obtained by 0.02 , while the maximum value obtained for 7.61 which means the higher the DER value indicates more companies use debt in funding.

In the sales growth variable the average value of the observation period is 0.3723 with the standard deviation of 1.13323 , it can be seen that the average growth of sales of real estate and property companies in observation year is around $0.37 \%$. Maximum score is $11.97 \%$ at PT. Laguna Cipta Griya Tbk

(LCGP) which recorded a fairly high sales growth in 2014. While the minimum value obtained at the same company that is PT. Laguna Cipta Griya Tbk (LCGP) with sales decline in 2015 of $-0.9 \%$.
In the liquidity variable the average value of the observation period is 2.8714 with the standard deviation of 5.43098, it can be seen that the average value of liquidity reflected in the current ratio of real estate and property companies in the observation year is quite good. Minimum value obtained by 0.07 , while the maximum value obtained for 59.71 which means that the value of liquidity is quite high with the availability of substantial current assets.

Furthermore, as a control variable data obtained known DPR lowest value of 0.00 , which means the company during the period did not distribute dividends while the highest value of 3.86. The DPR data obtained by the mean value of 0.1424 and a standard deviation of 0.43621 .

Then the last is the data Firm Size (LN_TA) the control variables known to the lowest value of 25.25 or about $135 \mathrm{M}$ and the highest was 31.54 around 37T. Firm Size Data obtained average value of assets that have been in logarithm of 28.62 and a standard deviation of 1.50627 .

\subsection{Statistical Test $t$}

This test is conducted to determine the partial independent variables significantly influence or not to the depended variable. The basis for the decision is to look at the column of significance that should be smaller than 0.05 . With the data program Statistical Package for Social Science (SPSS), found the following results :

\subsection{Discussion of Research Results}

From Table 1 above it can be seen that the leverage has a significance value of 0.017 , which means leverage significant effect on the value of the company at a significance level of 5\%. 
So it can be concluded that partial leverage positive effect on firm value. Based on this result, the $\mathrm{H}_{1}$ is accepted.

Sales growth have a significance value of 0.011 , which means sales growth significantly influence the value of the company at a significance level of $5 \%$. So it can be concluded that partial sales growth has a positive effect on firm value. Based on this result, the $\mathrm{H}_{2}$ is accepted.

Furthermore, liquidity variable is known to have a significance value of 0.075 which means that liquidity significantly affects the value of the company at the level of significance of $10 \%$. So it can be concluded that partially liquidity has a significant negative effect on firm value. Based on this result $\mathrm{H}_{3}$ is rejected.

In control variable that is dividend policy and firm size, test result show that dividend policy have positive significant effect with significance level of 0.059 at significant level of $10 \%$ significance. Then the firm size variable is known not to affect the value of the company with a significance level of 0.787 .

\subsection{1 $\mathrm{H}_{1}$ : Leverage positively affects Firm Value}

From the research, the partial testing leverage variable shows that there is a positive significant effect on firm value. Referring to the initial hypothesis of the study, the $\mathrm{H}_{1}$ of this research is supported by statistics. This means that the leverage has a significant positive effect on the value of the company and a similar study has been conducted by Hansen and Verawati (2014) with the results of that leverage has a significant positive effect on firm value. So that research results do not correspond to the research, conducted by Mahendra, Artini, and Suarjaya (2012) which stated that the leverage does not have an influence on the value of the company.
Real estate and property companies are using as well as additional funding for the operational assets of the company, of the need for an optimal debt will increase and proportional to the increase in the leverage ratio. Thus, the company with the optimal level of leverage has a positive effect on firm value. The trade-off theory explained that if the position of the capital structure is under optimal point then any additional debt will increase the value of the company and vice versa, each if the position of the capital structure is above the optimal point then any additional debt would lower the value of the company.

Basically, the real estate company has a fixed asset that a lot and it allows the company to use a larger debt. The high debt in real estate companies and property in these observations is still at the point of optimal and balanced in accordance benefits such debt so that it has a positive effect on firm value.

The use of leverage may also increase the company's operational activities due to debts, the company obtain sufficient capital and in the end also allows the company to survive and even thrive so it will be able to provide a high return to investors.

\subsection{2 $\mathrm{H}_{2}$ : Sales Growth positively affects Firm Value}

Testing in partial sales growth shows that there is a significant positive effect on firm value. Referring to the initial hypothesis of the study, the $\mathrm{H}_{2}$ in this study was supported by statistics. This means that sales growth had a significant positive effect on the value of the company and the results of this study according to research Sukaenah (2015) which states sales growth significant positive effect on the value of the company and is not in accordance with the research Limbago and Juniarti (2014) and Hansen Verawati and Juniarti (2014) which states that sales 
growth has no significant effect on firm value.

At the company's real estate and property sales growth becomes an important indicator for investors to assess the company's growth. So for companies that have a sales decline in the asset will cause negative stigma of investors to value the company, it is reflected in the background of the problems which the ELTY company recorded a decline significant marketing sales of about $94.61 \%$. The sales decline is considered to be a negative signal to investors about the company's growth.

In this regard, sales growth is a positive indicator to assess the value of the company, this is also because sales growth is an indicator for investors towards the company's growth in a better direction from year to year. The sales growth will be interpreted positively by investors as a company that has good prospects in the future, so that will increase the value of the firm.

\subsection{3 $\mathrm{H}_{3}$ : Liquidity positively affects Firm Value}

While the partial testing liquidity variables shows that there is a significant negative effect on firm value. Referring to the initial hypothesis of the study, the $\mathrm{H}_{3}$ in this study are not supported statistically. This means that liquidity has a negative effect on the value of the company and the research results are consistent with research of Wijaya and Purnawati (2013) which states that the liquidity significant negative effect on the value of the company and this research is not in accordance with the research of Mahendra, Artini, and Suarjaya (2012), which stated liquidity does not affect the value of the company.

Sawir (2005: 9) states that a low current ratio may have an impact on the company's stock price decline, but if too high can reduce the ability of the company's profit because many funds are idle. Their bad debts and inventory that has not sold can cause high current ratio. If it is more dominant in other current assets component of this course have an impact on the company's current ratio will be high and as if the company is in a liquid state.

Basically a high current ratio prove that the company has available assets are sufficient to pay the debt at any time the company liquidated, but the ratio is too high also shows bad management on the source of liquidity. To the excess of current assets should be used to pay dividends, pay long-term debt or for companies operations that then can generate more profit level. Because if not, then the investor will assume that the available funds can not be managed or invested optimally, then the final implication is negative stigma of of investors that affect the value of the company.

In addition to this, on the other hand the average value of the liquidity of real estate companies showed a high value so that when there is an increase in value this will have an impact as a negative influence due to liquidity has passed the optimum point in the average real estate companies and property on the Stock Exchange in the year of observation.

\section{CONCLUSION}

From the results, the conclusion that the leverage has a positive influence on the value of the firm, so the variable leverage hypothesis is accepted and supported by statistics. This is because the level of debt on the company's real estate and property in the BEI is still at the optimal point of the use of debt. So the addition of debt still provide benefits to corporate value.

For variable sales growth, the results of research known that sales growth had a positive effect on the value of the firm, so variable sales growth hypothesis is 
accepted and supported by statistics. The company's sales growth will be positive interpretation by investors as the company has good prospects for the future, thereby increasing the value of the company.

The results further showed that liquidity does not affect the value of the firm, it is because the value of liquidity in real estate companies and property are

\section{REFERENCES}

Almawadi, Issa. (2015). ELTY Pastikan Jual BTR dan Lido Resort. http:// http://m.kontan.co.id/news/eltypastikan-jual-btr-dan-lido-resort/ Retrieved May 7, 2015

Chung, Kee H. and Pruitt, Stephen W. (1994). A Simple Approximation of Tobin's Q. Financial Management, 23(3), 70-74

Eric B Lindenberg and Stephen A Ross. (1981). Tobin's Q Ratio and Industrial Organization, The Journal of Business, 54(1), 1-32

Ghozali, Imam. (2005). Aplikasi Analisis Multivariate dengan Program SPSS. Edisi 3. Badan Penerbit Universitas Diponegoro. Semarang.

Hansen, V. dan Juniarti. (2014). Pengaruh Family Control, Size, Sales Growth, dan Leverage Terhadap Profitabilitas dan Nilai Perusahan pada Sektor Perdagangan, Jasa, dan Investasi. Business Accounting Review, 2(1), 121-130

Limbago, E. (2014). Pengaruh Family Control Terhadap Profitabilitas dan Nilai perusahaan pada Sektor Properti dan Real Estate. Business Accounting Review, 2(1), 151-159

Mahendra Dj, Alfredo, Luh Gede Sri Artini, dan AA Gede Suarjaya. (2012). Pengaruh Kinerja Keuangan Terhadap Nilai already at the maximum point, so that when companies add current assets would likely cause the value of the company declined.

In this study, control variable dividend poilcy indicates that the variable has a positive effect, while firm size shows that the variable does not affect the value of the firm.
Perusahaan Pada Perusahaan Manufaktur Di Bursa Efek Indonesia. Jurnal Manajemen, Strategi Bisnis, dan Kewirausahaan, Fakultas Ekonomi Universitas Udayana. Denpasar. 6(2), 128-135

Sawir, Agnes, (2005). Analisa Kinerja Keuangan dan Perencanaan Keuangan Perusahaan, PT. Elex Media Komputindo. Jakarta

Sukaenah. (2015). Pengaruh Earning Per Share (EPS), Ukuran Perusahaan, Profitabilitas, Leverage, dan Sales Growth terhadap Nilai Perusahaan Industri Makanan dan Minuman yang Terdaftar di Bursa Efek Indonesia Tahun 2008-2013. Jurnal Ilmiah Mahasiswa. Universitas Pandanaran, Semarang. ISSN : 2442-4056. Vol 1 (1)

Wijaya, I.B.N.P \& Purnawati, N.K. (2014). Pengaruh Likuiditas dan Kepemilikan Institusional terhadap Nilai Perusahaan Dimoderasi oleh Kebijakan Dividen. E-Jurnal Manajemen, Universitas Udayana. Denpasar. 3(12)

Wiranuari, Andri. (2015). http://properti.liputan6.com/read/22 12324/pajak-properti-belum-jelaspenjualan-agung-podomoromerosot/ Retrieved May 7, 2015

Wolfe, J., \& Sauaia, A. C. A. (2003). 
Economics and Accounting Journal

Vol. 1, No. 3, September 2018

"The Tobin Q as A Company

Simulation and

Experiential

Performance

Indicator".

Learning, 30. 155-9

Developments in Business 